\title{
PENGARUH INTELLECTUAL CAPITAL DAN CORPORATE GOVERNANCE TERHADAP BUSINESS PERFORMANCE: PENDEKATAN PERSAMAAN STRUKTURAL
}

\author{
Desnoni Nandaria \\ Fakultas Ekonomi Universitas Islama Indonesia \\ e-mail: desnoninandaria@gmail.com \\ Hadri Kusuma \\ Fakultas Ekonomi Universitas Islama Indonesia \\ e-mail:hkusuma@uii.ac.id
}

\begin{abstract}
This study aims to analyze the effect of intellectual capital and corporate governance on the business performance and the influence of the financial performance on the market performance. This study extends the previous studies by adding indicators for each variable. The samples in this study were 36 companies from financial industries listed on the Indonesia Stock Exchange for the period from 2007 to 2011. Using partial least square (PLS) to process the data analysis. The findings show that intellectual capital significantly affected the financial performance, and corporate governance significantly influneced both financial performance and market performance. The Financial performance also had significant effect on the market performance. Those results and their implications of the study were also discussed on the last part of the paper.
\end{abstract}

Keywords: Intellectual Capital, Corporate Governance, BusinessPerformance

\begin{abstract}
Abstrak
Penelitian ini bertujuan untuk menganalisis pengaruh intellectual capital dan corporate governance terhadap business performance dan pengaruh financial performance terhadap market performance. Penelitian ini merupakan pengembangan penelitian sebelumnya dengan menambahkan indikator disetiap variabel. Sampel penelitian ini adalah 36 perusahaan dari industri keuangan yang terdaftar di Bursa Efek Indonesia untuk periode 2007 sampai 2011. Partial Least Square (PLS) digunakan untuk menganalisis data. Temuan menunjukkan bahwa intellectual capital berpengaruh signifikan terhadap financial performance, dan corporate governance berpengaruh signifikan terhadap financial performance dan market performance. Financial performance berpengaruh signifikan terhadap market performance. Hasil dan implikasi penelitian ini didiskusikan di bagian akhir penelitian ini.
\end{abstract}

Kata Kunci: Intellectual Capital, Corporate Governance, Business Performance

\section{PENDAHULUAN}

Bidang intellectual capital awalnya mulai muncul dalam pers populer pada awal 1990an. Di Indonesia, fenomena intellectual capital mulai berkembang terutama setelah munculnya Penyataan Standar Akuntansi Keuangan (PSAK) No.19 (revisi 2000) tentang aktiva tidak berwujud. Meskipun tidak dinyatakan secara eksplisit sebagai intellectual capital, namun lebih kurang intellectual capi- tal telah mendapat perhatian. Menurut PSAK No. 19, aktiva tidak berwujud adalah aktiva non-moneter yang dapat diidentifikasi dan tidak mempunyai wujud fisik serta dimiliki untuk digunakan dalam menghasilkan atau menyerahkan barang atau jasa, disewakan kepada pihak lainnya, atau untuk tujuan administratif (Ikatan Akuntan Indonesia 2002).

Penelitian mengenai hubungan intellectual capital terhadap business performance 
di luar negeri maupun di Indonesia telah dibuktikan secara empiris. Firer dan Williams (2003), Belkaoui (2003), Astuti (2005), Tan et al. (2007), Ulum et al. (2008), dan Solikhah et al. (2010) berhasil membuktikan intellectual capital berpengaruh positif pada kinerja keuangan perusahaan. Akan tetapi, salah satu area yang menarik perhatian akademisi maupun praktisi adalah terkait dengan kegunaan intellectual capital sebagai salah satu alat untuk menentukan nilai perusahaan (Edvinsson dan Malone 1997). Nilai pasar dari beberapa perusahaan dapat beberapa kali lebih besar dari nilai buku aset perusahaannya. Adanya "hidden value" yang tergambar dari persentasi nilai pasar mengindikasikan bahwa perusahaan memiliki intellectual capital. Banyak perusahaan yang memiliki aktiva berwujud yang tidak signifikan dalam laporan keuangan namun penghargaan pasar atau nilai perusahaan tersebut sangat tinggi (Mahmud 2013; Nandaria 2013).

Jaafari (2013) meneliti hubungan jangka panjang intellectual capital dengan nilai pasar dan kinerja keuangan perusahaan yang terdaftar di Bursa Saham Iran. Komponen intellectual capital (human capital, structur capital, dan customer capital) diukur dengan metode Pulic (VAIC ${ }^{\mathrm{TM}}$ ) dan kinerja perusahaan diukur dengan market to book value, Return on Asset (ROA), Return on equity (ROE), dan growth in revenue (GR). Hasilnya menunjukkan adanya hubungan yang signifikan positif antara intellectual capital, nilai pasar, dan kinerja keuangan. Penelitian Chen et al. (2005) dengan menggunkan kinerja perusahaan yang berupa market-tobook value, ROE, ROA, growth in revenue dan employee productivity menunjukkan bahwa intellectual capital berpengaruh terhadap nilai pasar dan kinerja keuangan.

Namun demikian, hasil penelitian yang dilakukan Jaafari (2013) dan Chen et al. (2005) berbeda dengan hasil penelitian yang dilakukan oleh Gan dan Saleh (2008) pada perusahaan Technology-Intensive di Malaysia yang menemukan bahwa intellectual capital berpengaruh positif terhadap kinerja keuangan (ROA, Asset turn over, ATO) tetapi tidak terdapat hubungan antara intellectual capital dengan nilai pasar yang diproksikan dengan market to book value. Hasil ini dikarenakan periode pengamatan yang terlalu pendek (tahun 2007s/d 2008), sehingga belum mampu menunjukkan pengaruh yang signifikan terhadap kinerja pasar perusahaan di Malaysia.

Terkait dengan penelitian tentang intellectual capital, corporate governance, dan kinerja perusahaan, Ningrum (2012) berhasil menunjukkan bahwa intellectual capital berpengaruh positif terhadap kinerja keuangan (ROA) perusahaan namun untuk corporate governance yang hanya diproksikan dengan kepemilikan manajerial, kepemilikan institusional, dan proporsi komisaris independen, masih tidak terbukti dapat meningkatkan kinerja keuangan pada perusahaan keuangan yang terdaftar di Bursa Efek Indonesia periode pengamatan 2009-2011.

Penelitianpenelitian tersebut masih menunjukkan hasil yang berbeda. Hal ini dikarenakan adanya perbedaan proksi yang digunakan untuk mengukur masing-masing variabel, dan periode pengamatan yang dilakukan (Mahmud, 2013; Nandaria, 2013). Melihat penelitian Gan dan Saleh (2008) dan Ningrum (2012), peneliti mengkaji keterkaitan intellectual capital, corporate governance, dan kinerja perusahaan, khususnya perusahaan keuangan yang terdaftar di Bursa Efek Indonesia. Menyempurnakan penelitian-penelitian sebelumnya, proksi pengukuran variabel ditabahkan. Komponen intellectual capital (structur capital, human capital, dan customer capital) diukur dengan metode Pulic (VAIC $^{\mathrm{TM}}$ ) yang mengacu pada penelitian Jaafari (2013) dan Chen et al. (2005). Untuk menilai corporate governance, peneliti menambahkan proksi jumlah anggota komite audit dan ukuran dewan komisaris. Untuk penilaian terhadap kinerja keuangan perusahaan, peneliti menggunakan proksi ROA, ROE, ATO, dan GR, sedangkan untuk menilai kinerja pasar perusahaan peneliti menggabungkan proksi-proksi penelitian terdahulu yaitu MBV, PER, harga pasa saham per lembar, dan Tobin's Q. Dalam penelitian ini juga digunakan variabel kontrol untuk 
mengendalikan agar hubungan yang terjadi pada variabel dependen tersebut murni dipengaruhi oleh variabel independen bukan oleh faktor-faktor lain, yaitu ukuran perusahaan dan leverage.

\section{TINJAUAN PUSTAKA DAN PERUMUSAN HIPOTESIS}

\section{Teori dasar}

Lima teori yang digunakan dalam penelitian ini. Teori-teori tersebut adalah Stakeholder Theory, Resource Based Theory (RBT), Market Based Theory, Agency Theory dan Signaling Theory. Teori stakeholder mempertimbangkan posisi para stakeholder yang dianggap powerfull. Kelompok stakeholder inilah yang menjadi pertimbangan utama bagi perusahaan dalam mengungkapkan dan/atau tidak mengungkapkan suatu informasi di dalam laporan keuangan. Dalam pandangan teori ini, perusahaan memiliki stakeholders, bukan hanya sekedar shareholder. Perusahaan memandang bahwa stakeholders terdiri dari pemegang saham, kreditur, pemerintah, karyawan, pelanggan, pemasok, dan publik (Belkaoui 2003).

Tujuan utama dari teori ini adalah untuk membantu manajemen perusahaan dalam meningkatkan penciptaan nilai sebagai dampak dari aktivitas-aktivitas yang mereka lakukan dan meminimalkan kerugian yang mungkin muncul bagi stakeholder mereka. Sebenarnya, teori ini menjelaskan hubungan antara manajemen perusahaan dengan para stakeholder-nya. Para stakeholder memiliki hak untuk diperlakukan secara adil oleh organisasi, dan manajemen harus mengelola organisasi untuk keuntungan seluruh stakeholder. Dalam upaya penciptaan nilai bagi perusahaan, manajemen perusahaan harus dapat mengelola seluruh sumberdaya yang dimiliki perusahaan, baik karyawan (human capital), aset fisik (physical capital) maupun structural capital.

Resource based theory dipelopori oleh Penrose (1959), yang mengemukakan bahwa sumberdaya yang dimiliki perusahaan bersifat heterogen dan memiliki karakteristik khusus dan unik di setiap perusahaan. Resource based theory adalah suatu pemikiran yang berkembang dalam teori manajemen strategik dan keunggulan kompetitif perusahaan yang meyakini bahwa perusahaan akan mencapai keunggulan apabila memiliki sumberdaya yang unggul. Sumberdaya yang unggul adalah sumberdaya yang langka, susah untuk ditiru oleh pesaing, dan tidak tergantikan.

MenurutSusanto (2007), agar dapat bersaing organisasi membutuhkan dua hal utama. Pertama, memiliki keunggulan dalam sumberdaya yang dimilikinya, baik berupa aset yang berwujud (tangible assets) maupun yang tidak berwujud (intangible assets). Kedua, kemampuan dalam mengelola sumberdaya yang dimiliki secara efektif dan efisien. Kombinasi yang apik dari keduanya akan menciptakan kompetensi yang khas dari sebuah perusahaan, sehingga mampu memiliki keunggulan kompetitif di banding para pesaingnya. Karenanya, berdasarkan pendekatan resource based theory dapat disimpulkan bahwa sumberdaya yang dimiliki perusahaan berpengaruh terhadap kinerja perusahaan yang pada akhirnya akan meningkatkan nilai pasar perusahaan (Penrose, 1959).

Market Based Theory (MBT) memandang bahwa kinerja perusahaan tidak hanya ditentukan oleh faktor- faktor internal tetapi juga oleh faktor-faktor eksternal. Menurut Susanto (2007), konsep MBT ini didasarkan atas konsep competitive force model. Model ini menjelaskan lima faktor pendorong eksternal yang harus diperhatikan oleh sebuah organisasi agar mampu memperoleh keunggulan kompetitif dalam lingkungan bisnis, yaitu: (1) Ancaman pemain baru dalam bisnis (2) Persaingan diantara perusahan-perusahaan yang berbeda dalam industri (3) Ancaman adanya produk atau layanan pengganti (4) Kekuatan pemasok (5) Kekuatan pembeli.

Kekuatan kolektif dari kelima faktor pendorong ini akan menentukan potensi keuntungan secara keseluruhan dalam sebuah industri. Setiap industri memiliki seperangkat karakteristik ekonomi dan teknis yang menentukan kekuatan masing-masing faktor pendorong ini. Berdasarkanmarket based 
theory, faktor-faktor eksternal ini merupakan faktor pendorong bagi perusahaan untuk menentukan dan memiliki sumberdaya strategik yang mampu menjadi sumber keunggulan kompetitif dalam lingkungan bisnis dengan tingkat persaingan yang tinggi.

Teori keagenan (Agency Theory) mengemukakan hubungan antara principal (pemilik) dan agent (manajer) dalam hal pengelolaan perusahaan, dimana principal merupakan suatu entitas yang mendelegasikan wewenang untuk mengelola perusahaan kepada pihak agent (manajemen). Perbedaan peran di antara keduanya menyebabkan suatu ketimpangan informasi (Jensen dan Meckling 1976). Eisenhardt (1989) menyatakan bahwa teori agensi menggunakan tiga asumsi sifat manusia: (1) Manusia pada umumnya mementingkan diri sendiri (self interest) (2) Manusia mempunyai daya pikir terbatas mengenai persepsi masa mendatang (bounded rationality) (3) Manusia selalu menghindari risiko (risk averse).

Corporate governance merupakan konsep yang didasarkan pada teori keagenan yang sangat berkaitan dengan bagaimana membuat para investor yakin bahwa manajer akan memberikan keuntungan bagi mereka, yakin bahwa manajer tidak akan menggelapkan atau menginvestasikan ke dalam proyek-proyek yang tidak menguntungkan berkaitan dengan modal yang telah ditanamkan oleh investor, dan juga berkaitan dengan bagaimana para investor mengontrol para manajer (Jensen dan Meckling 1976). Dengan kata lain corporate governance diharapkan akan dapat berfungsi untuk menekan atau menurunkan biaya keagenan.

Teori sinyal (Signaling Theory) menyatakan bahwa terdapat dorongan perusahaan untuk memberikan informasi laporan keuangan tahunan kepada pihak eksternal yang dapat menjadi sinyal bagi investor dan pihak potensial lainnya dalam mengambil keputusan ekonomi (Ujiyantho dan Pramuka 2007; Brigham dan Houston 2011). Suatu pengungkapan dikatakan mengandung informasi apabila dapat memicu reaksi pasar, yaitu dapat berupa perubahan harga saham atau abnormal return.
Apabila pengungkapan tersebut memberikan dampak positif berupa kenaikan harga saham, maka pengungkapan tersebut merupakan sinyal positif. Begitupun sebaliknya.

Seorang manajer memiliki motivasi untuk mengungkapkan private information (informasi keuangan dan non-keuangan) secara sukarela karena perusahaan berharap informasi tersebut dapat diinterpretasikan sebagai sinyal positif mengenai kinerja perusahaan dan mampu mengurangi asimetri informasi. Pengungkapan intellectual capital dan corporate governance memungkinkan bagi investor danstakeholder lainnya untuk lebih baik dalam menilai kemampuan perusahaan di masa depan, melakukan penilaian yang tepat terhadap perusahaan, dan mengurangi persepsi risiko (Williams 2001). Berdasarkan teori ini maka suatu pengungkapan laporan tahunan perusahaan merupakan informasi yang penting dan dapat mempengaruhi investor dalam proses pengambilan keputusan.

\section{Pengaruh Intellectual Capital terhadap Financial dan Market Performance}

Menurut teori stakeholder, manajemen perusahaan diharapkan mampu melakukan aktivitas yang diharapkan oleh stakeholder mereka dan para stakeholder dapat mengendalikan manajemen dalam mengelola sumberdaya yang dimiliki perusahaan. Sejalan dengan teori RBT, perusahaan yang mampu menggunakan dan mengelola sumberdaya yang dimilikinya baik berupa aset berwujud maupun aset yang tidak berwujud secara efektif dan efisien maka hal tersebut dapat menciptakan value added dan keunggulan kompetitif dibanding para pesaingnya. Dalam artikelnya, Stewart (1991) mendefinisikan intellectual capital sebagai sesuatu kenggulan kompetitif berupa intelektual pengetahuan, informasi, kekayaan intelektual dan pengalaman yang dapat membuat kekayaan.

Jadi dapat disimpulkan bahwa intellectual capital merupakan sumberdaya perusahaan yang berbasis pengetahuan dan berupa asset tidak berwujud sehingga dapat dijadikan nilai tambah bagi perusahaan dengan mem- 
perhatikan human capital, structural capital dan customer capital yang dimiliki perusahaan. Intellectual capital ini mampu digunakan perusahaan untuk menciptakan inovasi dan persaingan bisnis yang kompetitif.

IFAC (1998) dalam Ulum (2009) mengklasifikasikan intellectual capital dalam tiga kategori, yaitu organizational capital, relational capital, dan human capital. Organizational capital meliputi intellectual property dan infrastructure assets. Peneliti terdahulu (Sveiby 1997; Edvinsson dan Malone 1997; Chen et al. 2005; Jaafari 2013) pada umumnya menyatakan bahwa intellectual capital terdiri dari tiga komponen utama, yaitu human, structural dan customer capital.

Human capital merupakan lifeblood dalam intellectual capital. Pada human capital inilah terdapat sumber innovation dan im provement berupa pengetahuan, keterampilan, dan kompetensi yang dimiliki oleh karyawan perusahaan. Akan tetapi human capital merupakan komponen yang sulit diukur (Sawarjuwono dan Kadir 2003). Oleh karena itu, human capital merupakan sumberdaya kunci yang dapat menciptakan keunggulan kompetitifperusahaan sehingga perusahaan mampu bersaing dan bertahan di lingkungan bisnis yang dinamis. Dengan memiliki karyawan yang berkeahlian dan berketerampilan khusus, maka dapat meningkatkan kinerja perusahaan dan menjamin keberlangsungan perusahaan tersebut. Meningkatnya kinerja perusahaan juga akan meningkatkan persepsi pasar.

Structural capital merupakan kemampuan organisasi atau perusahaan dalam memenuhi proses rutinitas perusahaan dan strukturnya yang mendukung usaha karyawan untuk menghasilkan kinerja intelektual yang optimal serta kinerja bisnis secara keseluruhan (Sawarjuwono dan Kadir 2003). Structural capital adalah sarana dan prasarana yang mendukung karyawan untukmenciptakan kinerja yang optimum, meliputi kemampuan organisasi menjangkau pasar, hardware, software, database, struktur organisasi, patent, trademark, dan segala kemampuan organisasi untuk mendukung produktivitas karyawan. Konsep adanya modal struktural memungkin- kan terciptanya intellectual capital dan menjadi penghubung atau pemroses sumberdaya manusia menjadi intellectual capital.

Konsep penting customer capital adalah pengetahuan yang dibentuk dalam marketing channels bahwa organisasi berkembang dengan menjalankan bisnis. Sebagai contoh adalah image, loyalitas konsumen, kepuasan konsumen, hubungan dengan supplier, kekuatan komersial, kapasitas negosiasi dengan entitas keuangan dan lingkungan aktivitas (Sawarjuwono dan Kadir 2003).

Penelitian mengenai hubungan intellectual capital terhadap kinerja keuangan perusahaan di luar negeri maupun di Indonesia telah dibuktikan secara empiris. Firer dan Williams (2003) dari Afrika Selatan melakukan penelitian dengan metode Pulic VAIC $^{\mathrm{TM}}$ dan regresi linier dengan hasil intellectual capital (IC) berhubungan positif dengan kinerja keuangan perusahaan (ROA, ATO). Hasil tersebut sejalan dengan penelitian Belkaoui (2003) dari USA yang menggunakan metode regresi dan laporan tahunan, bahwa intellectual capital secara signifikan mening katkan dengan kinerja perusahaan multinasional di USA. Selanjutnya, Tan et al. (2007) dari Singapore melakukan penelitian dengan metode Pulic (VAIC ${ }^{\mathrm{TM}}$ ) dan PLS dengan hasil IC berpengaruh positif terhadap kinerja keuangan perusahaan, baik masa kini maupun masa mendatang; rata-rata pertumbuhan IC berhubungan positif dengan kinerja keuangan perusahaan di masa mendatang; kontribusi IC terhadap kinerja perusahaan berbeda berdasarkan jenis industrinya.

Ulum (2008) meneliti hubungan intellectual capital terhadap kinerja perusahaan perbankan Indonesia. Kinerja perusahaan yang digunakan adalah ROA, ATO, dan GR. Hasil penelitian ini menunjukkan bahwa IC berpengaruh signifikan positif terhadap kinerja keuangan perusahaan sekarang dan masa depan. Diperkuat dengan penelitian Ningrum (2012) yang juga berhasil menunjukkan bahwa intellectual capital yang diukur dengan metode Pulic (VAIC ${ }^{\mathrm{TM}}$ ) berpengaruh positif terhadap kinerja keuangan (ROA). Karenanya berdasarkan teori-teori yang telah dikemuka- 
kan disertai dengan penelitian-penelitian terdahulu terkait pengaruh intellectual capital dan kinerja keuangan, maka dirumuskan hipotesis sebagai berikut:

$\mathrm{H}_{1}$ : Intellectual capital berpengaruh positif terhadap financial performance perusahaan

Teori stakeholder juga menyatakan bahwa perusahaan bukanlah entitas yang hanya beroperasi untuk kepentingannya sendiri namun harus memberikan manfaat bagi stakeholdernya (Ghozali dan Chariri 2007 dalam Rani 2012). Sejalan dengan teori signaling yang mengemukakan bahwa adanya dorongan perusahaan untuk memberikan informasi pelaporan keuangan tahunan kepada pihak eksternal, menjadi sinyal bagi investor dan pihak potensial lainnya dalam mengambil keputusan ekonomi. Suatu pengungkapan dikatakan mengandung informasi apabila dapat memicu reaksi pasar, yaitu dapat berupa perubahan harga saham atau abnormal return. Apabila pengungkapan tersebut memberikan dampak positif berupa kenaikan harga saham, maka pengungkapan tersebut merupakan sinyal positif. Sebaliknya apabila pengungkapan memberikan dampak negatif berupa abnormal return mengindikasikan adanya sinyal negatif terhadap kinerja pasar perusahaan.

Intellectual capital diyakini memegang peran penting dalam meningkatkan nilai perusahaan di mata pasar. Intellectual capital mampu menciptakan inovasi dan persaingan bisnis yang kompetitif. Untuk dapat menarik perhatian pasar, perusahaan harus mampu meningkatkan pengelolaan kinerjaintellectual capital-nya. Hal tersebut dapat memperlihatkan bahwa perusahaan mempunyai nilai tambah dibandingkan dengan perusahaan lain, sehingga investor akan menempatkan nilai yang lebih tinggi untuk perusahaan yang memiliki intellectual capitalyang besar. Semakin tinggi intellectual capital dalam suatu perusahaan, maka nilai perusahaan akan meningkat dan sahamnya akan banyak diminati oleh investor sehingga harga saham cenderung menjadi naik.
Penelitian terkait adanya hubungan positif antara intellectual capital dengan kinerja pasar perusahaan juga telah dilakukan secara empiris oleh Chen et al. (2005) dan Jaafari (2013). Jaafari (2013) meneliti hubungan jangka panjang intellectual capital dengan nilai pasar dan kinerja keuangan perusahaan yang terdaftar di Bursa Saham Iran. Komponen intellectual capital (human capital, structur capital, dan customer capital) diukur dengan metode Pulic (VAIC ${ }^{\mathrm{TM}}$ ) dan kinerja perusahaan diukur dengan market to book value, $\mathrm{ROA}, \mathrm{ROE}$, dan growth in revenue. Hasil penelitian Jaafari (2013) menunjukkan adanya hubungan yang signifikan positif antara intellectual capital, nilai pasar, dan kinerja keuangan. Penelitian Chen et al. (2005) juga menguji pengaruh intellectual capital terhadap nilai pasar dan kinerja keuangan perusahaan. Chen et al. (2005) juga menggunakan model Pulic (VAIC ${ }^{\mathrm{TM}}$ ) dengan sampel perusahaan publik di Taiwan. Kinerja perusahaan diukur dengan market-to-book value, $\mathrm{ROE}, \mathrm{ROA}$, growth in revenue dan employee productivity. Hasil penelitian Chen et al. (2005) menunjukkan bahwa intellectual capital berpengaruh terhadap nilai pasar dan kinerja keuangan; RdanD berpengaruh terhadap kinerja perusahaan. Oleh karena itu, hipotesis yang diajukan dalam penelitian ini adalah:

$\mathrm{H}_{2}$ : Intellectual capital berpengaruh positif terhadap market performance

\section{Pengaruh Corporate Governance terhadap Financial dan Maket Performance}

Corporate governance merupakan seperangkat sistem yang mengatur dan mengendalikan perusahaan untuk menciptakan nilai tambah (value added) bagi para pemangku kepentingan. Sedangkan menurut Cadbury Committee (1992), corporate governance yang baik adalah prinsip yang mengarahkan dan mengendalikan perusahaan agar mencapai keseimbangan antara kekuatan serta kewenangan perusahaan dalam memberikan pertanggungjawabannya kepada para shareholders khususnya, dan stakeholders pada umumnya. OECD (1999) menggambarkan 
bahwacorporate governance merupakan suatu elemen kunci dalam meningkatkan efisiensi ekonomis, yang meliputi serangkaian hubungan antara manajemen perusahaan, dewan direksi dan komisaris, para pemegang saham dan stakeholders lainnya.

Inti dari corporate governance adalah adanya pemisahan antara kepemilikan dengan pengendalian perusahaan, yaitu untuk mengatasi masalah yang timbul dari hubungan antara pemilik modal dengan manajer. Permasalahan tersebut adalah keterbatasan pemilik dalam memastikan bahwa modal yang ditanamkannya tidak diambil alih atau diinvestasikan pada proyek yang tidak menguntungkan. Corporate governance terdiri dari lima prinsip yaitu: transparency (transparansi), accountability (akuntabilitas), responsibility (pertanggungjawaban), independency (independensi), fairness (keadilan dan kewajaran) (Ningrum 2012). Mekanisme corporate governance meliputi kepemilikan institusional, kepemilikan manajerial, ukuran dewan komisaris, proporsi komisaris independen, dan keberasaan komite audit. Dengan adanya mekanisme corporate governance tersebut diharapkan dapat menjadi alat untuk mengawasi perusahaan agar kinerja perusahaan menjadi semakin baik.

Dengan adanya tata kelola perusahaan yang baik dan terkendali, keselarasan tujuan antara seluruh pihak yang berkepentingan terhadap perusahaan dapat terwujud sehingga seluruh elemen-elemen yang terkait dapat bekerja sama dalam menjalankan kegiatan bisnis secara maksimal. Kinerja keuangan perusahaan pun akan mengalami peningkatan seiring dengan peningkatan pengelolaan perusahan dalam mencapai tujuannya. Keberhasilan mekanisme corporate governance suatu perusahaan tercermin dalamcorporate performance. Corporate governance dapat diukur berdasarkan economic value added (Susanto 2003). Berdasarkan uraian tersebut maka keberhasilan mekanisme corporate governance tercermin dalam corporate performance, dimana corporate performance dapat diukur dari return on capital (ROC), returnon equity (ROE) dan economic value added (EVA).

Jensen dan Meckling (1976) mengemukakan bahwa perusahaan dengan governance yang baik akan memiliki kinerja keuangan yang lebih efisien. Sejalan dengan penelitian yang dilakukan Klapper dan Love (2002) yang berhasil menemukan adanya hubungan positif antara corporate governance dengan kinerja keuangan yang diukur dengan ROA. Corporate governance merupakan pedoman bagi manajer untuk mengelola perusahaan secara best practice. Manajer bekerja secara efektif dan efisien sehingga dapat menurunkan biaya modal dan mampu meminimalkan risiko. Hal ini dapat terlihat pada harapan aliran kas masa depan yang tinggi sehingga profitabilitas yang diharapkan juga akan semakin meningkat. Hipotesis alternatif yang diajukan dalam penelitian ini adalah:

$\mathrm{H}_{3}$ :Corporate Governance berpengaruh positif terhadap financial performance

Seperti diuraikan sebelumnya, teori signaling berkaitan dengan dorongan perusahaan untuk memberikan informasi laporan keuangan tahunan kepada pihak eksternal untuk mengurangi informasi yang dimiliki, baik informasi keuangan maupun non keuangan, dan sebagai sinyal positif mengenai kinerja perusahaan (Susanto 2007). Salah satu informasi yang wajib untuk diungkapkan oleh perusahaan adalah informasi tentang corporate governance. Pelaksanaan corporate governance yang baik secara konsisten dan konsekuen di setiap kegiatan bisnis serta menjadikannya sebagai budaya kerja yang berlaku di perusahaan, dapat mendukung tujuan perusahaan baik pertumbuhan usaha, profitabilitas, meningkatkan nilai pemegang saham dan pemangku kepentingan lainnya, serta meningkatkan kemampuan agar keberlangsunganusaha jangka panjang dapat dicapai. Investor akan merasa aman atas investasinya, cenderung memperoleh return sesuai dengan harapannya dan bersedia membayar premium kepada perusahaan yang menerapkan good corporate governance (Jensen dan Meckling 1976). 
Ada dua alasan umum bahwa corporate governance meningkatkan nilai perusahaan. Pertama, corporate governance mening katkan kepercayaan investor. Investor beranggapan bahwa perusahaan yang dikelola dengan baik maka risikonya kecil dan menunjukkan expected rate of returnyang rendah sehingga menyebabkan tingginya penilaian perusahaan. Kedua, untuk menunjukkan bahwa corporate governance merupakan faktor yang penting dalam menentukan nilai perusahaan (Jensen dan Meckling 1976). Berdasarkan atas argumen di atas dan ulasan teoritis, maka hipotesis kedua yang dirumuskan dalam bentuk alternatif adalah:

$\mathrm{H}_{4}$ : Corporate Governance berpengaruh positif terhadap market performance

\section{Pengaruh Financial Performance terhadap Business Performance}

Kinerja (Performance) merupakan efektifitas operasional perusahaan yang ditetapkan berdasarkan tujuan yang ingin dicapai oleh perusahaan. Kinerja perusahaan merupakan prestasi yang dicapai oleh suatu perusahaan dalam suatu periode tertentu yang mencerminkan tingkat kesehatan perusahaan. Kinerja perusahaan dibedakan menjadi dua, yaitu kinerja keuangan dan kinerja pasar perusahaan. Financial Performance merupakan penentuan ukuran-ukuran tertentu yang dapat mengukur keberhasilan suatu perusahaan dalam menghasilkan laba. Prestasi perusahaan ditunjukkan dalam laporan keuangansebagai tampilan keadaan suatu perusahaan selama periode tertentu disebut dengan kinerja keuangan perusahaan. Pengukuran kinerja keuangan sangat diperlukan dalam relasi dengan kepuasan konsumen proses internal, dan aktivitas yang berhubungan dengan perbaikan dan inovasi dalam organisasi yang membawa pada future financial return. Kinerja perusahaan dapat diukur melalui rasio keuangan seperti Return on Asset (ROA), Return on Equity (ROE), Assets Turnover (ATO, dan Growth in Revenue (GR) (Chen et al 2005).

Market Performance (Kinerja Pasar) menggambarkan kinerja perusahaan yang menunjukan keefektifan, presentasi atau keatraktifan pasar suatu produk perusahaan. Pertumbuhan perusahaan yang terus meningkat pun diharapkan meningkat apabila kinerja perusahaan baik. Pada penelitian ini, untuk mengukur kinerja pasar perusahaan peneliti menggabungkan proksi-proksi dari beberapa penelitian sebelumnya. Kinerja pasar pada penelitian ini diukur dengan market to book value (Chen et al. 2005; Imaningati 2007; Jaafari 2013), price to book value (PBV) (Husnan et al. 2006; Rani 2012), price earning ratio (PER) (Wijaya dan Wibawa 2010), dan Tobin's Q (Klapper dan Love 2002). Ratio ini mengukur nilai yang diberikan pasar keuangan kepada manajemen dan organisasi sebagai perusahaan yang terus tumbuh. Dipilih sebagai ukuran kinerja karena menggambarkan besarnya premi yang diberikan pasar atas intellectual capital dan corporate governance yang dimiliki perusahaan.

Menurut teori stakeholder, para stakeholder mungkin lebih menyenangi perusahaan yang bisa menciptakan nilai bagi kepentingannya. Jika stakeholdernya berupa calon investor maka mereka memiliki kepentingannya terhadap perusahaan yang kinerjanya baik. Para investor tersebut berharap mendapatkan keuntungan dari modal yang ditanamkan di perusahaan tersebut (Mahmud 2013; Nandaria 2013). Dengan demikian perusahaan yang kinerjanya baik maka akan mampu memenuhi kepentingan stakeholder sehingga saham perusahaan tersebut mungkin banyak diminati dan akhirnya harga sahamnya akan meningkat (Belkaoui 2003).Selanjutnya menurut teori sinyal. Kinerja keuangan perusahaan yang benar-benar baik memberikan signal kepada pihak eksternal (Susanto 2007). Contohnya dalam pemberian deviden, pemberian deviden merupakan signal dari perusahaan bahwa perusahaannya dalam kondisi baik atau laba. Semakin tinggi kinerja keuangan suatu perusahaan maka kinerja pasar suatu perusahaan juga akan meningkat karena kinerja keuangan selalu berhubungan dengan kinerja pasar. Hipotesis yang diajukan dalam penelitian ini adalah: 
$\mathrm{H}_{5}$ : Financial performance berpengaruh positif terhadap market performance

\section{METODA PENELITIAN}

\section{Populasi dan Sampel Penelitian}

Populasi dalam penelitian ini adalah semua perusahaan atau industri keuangan yang terdaftar di Bursa Efek Indonesia (BEI). Periode pengamatan dalam penelitian ini adalah tahun 2008-2012. Teknik pengambilan sampel dalam penelitian ini adalah dengan menggunakan metode purposive sampling. Adapun jumlah sampel yang memenuhi kriteria tampak pada tabel 1 .

\section{Variabel Penelitian}

Definisi dan indikator pengukurann dari setiap variabel beserta rujukannya seperti yang tersaji pada tabel 2 di bawah ini.

Tabel 1: Distribusi Sampel

\begin{tabular}{llc}
\hline No. & \multicolumn{1}{c}{ Keterangan } & $\begin{array}{c}\text { Jumlah } \\
\text { Perusahaan }\end{array}$ \\
\hline 1. & $\begin{array}{l}\text { Perusahaan keuangan yang terdapat di Bursa Efek Indonesia (BEI) tahun } \\
\text { 2007, 2008, 2009, 2010, dan 2011 }\end{array}$ & 63 \\
2. & $\begin{array}{l}\text { Perusahaan yang tidak menyajikan data laporan keuangan selama tahun } \\
\text { pengamatan }\end{array}$ & 0 \\
3. & $\begin{array}{l}\text { Perusahaan yang memperoleh ekuitas negatif selama periode pengamatan } \\
\text { 4. }\end{array}$ & $\begin{array}{c}\text { Perusahaan yang memperoleh laba negatif selama periode pengamatan } \\
\text { Jumlah Sampel }\end{array}$ \\
& $\quad$ Jumlah Sampel Pengamatan selama 5 tahun & 36 \\
\hline
\end{tabular}

Tabel 2: Variabel penelitian

\begin{tabular}{ll}
\hline \multicolumn{1}{c}{ Variabel } & \multicolumn{1}{c}{ Referensi } \\
\hline Intellectual capital (Value Added Intellectual Coefficient, & \\
VAIC) & Ulum (2008); Ningrum (2012) \\
Value Added Capital Employed (VACA) & Ulum (2008); Ningrum (2012) \\
Value Added Human Capital (VAHU) & Ulum (2008); Ningrum (2012) \\
Structural Capital Value Added (STVA) & \\
Coporate Governance & Eng dan Mak (2003) \\
Persentase Kepemilikan Institusional (KPI) & Sembiring (2005) \\
Persentase Kepemilikan Manajerial (KPM) & Dewi (2011) dan Ningrum (2012) \\
Proporsi Komisaris Independen (PKI) & Sembiring (2005) \\
Jumlah Dewan komisaris (UDK) & Dewi (2011) dan Ningrum (2012) \\
Jumlah Komite Audit (KA) & \\
Financial Performance & Chen et al (2005) \\
Return on Equity (ROE) & Chen et al (2005) \\
Return on Assets (ROA) & Chen et.al (2005) \\
Growth Revenue (GR) & Firer dan William (2003) \\
Assets Turn Over (ATO) & \\
Market Performance & Chen et al (2005) dan Jaafari (2013) \\
Market to Book Value (MVB) & Jaafari (2013) \\
Harga Per lembar saham & Wijaya dan Wibawa (2010) \\
Price Earning Ratio (PER) & Klapper dan Love (2002) \\
Tobin's Q & \\
Control Variable & Pamungkas (2013) \\
Log asset & Husnan dan Pudjiastuti (2006) \\
Leverage &
\end{tabular}




\section{Model Penelitian}

Pengujian hipotesis dilakukan dengan menggunakan persamaan 1 sampai dengan 5 . Persamaan tersebut menggambarkan persamaan structural.

$\mathrm{FP}=\beta_{1} \mathrm{IC}+\beta_{5} \mathrm{Ctrl}+\mathrm{Z}_{1}$
$\mathrm{MP}=\beta_{2} \mathrm{IC}+\beta_{6} \mathrm{Ctrl}+\mathrm{Z}_{2}$
$\mathrm{FP}=\beta_{3} \mathrm{CG}+\beta_{5} \mathrm{Ctrl}+\mathrm{Z}_{1}$
$\mathrm{MP}=\beta_{4} \mathrm{CG}+\beta_{6} \mathrm{Ctrl}+\mathrm{Z}_{2}$
$\mathrm{MP}=\beta_{5} \mathrm{FP}+\mathrm{Z}_{3} \ldots \ldots \ldots \ldots \ldots \ldots \ldots \ldots \ldots \ldots \ldots$

Dimana:

$$
\begin{aligned}
& \mathrm{FP}=\text { Financial Performance } \\
& \mathrm{MP}=\text { Market Performance } \\
& \mathrm{IC}=\text { Intellectual Capital } \\
& \mathrm{CG}=\text { Corporate Governance } \\
& \beta=\text { Konstanta } \\
& \mathrm{Ctrl}=\text { Variabel Kontrol } \\
& \mathrm{Z}=\text { Error }
\end{aligned}
$$

Uji validitas persamaan structural tersebut menggunakan descriminant validity dan average variance extracted. Dengan menggunakan descriminant validity menunjukan bahwa indikator GR, PER dan STVA dikeluarkan dari model penelitian karena datanya tidak valid. Indikator-indikator tersebut secara statistik tidak signifikan. Hasil yang sama diberikan bila uji validitas menggunakan average variance extracted. Nilai AVE untuk variabel Financial performance, market performance, intellectual capital, corporate governance, dan variabel kontrol lebih besar daripada 0,50. Hasil ini menunjukkan bahwa variabel Financial performance, market performance, intellectual capital, dan corporate governance adalah valid. Sementara itu uji reliabilitas menggunakan nilai composite reliability. Nilai composite reliability dari semua variabel financial performance, market performance, intellectual capital, dan variabel kontrol melebihi 0,70. Dengan demikian dapat disimpulkan bahwa variabel-variabel tersebut reliabel atau dapat dipercaya.

\section{HASIL DAN PEMBAHASAN}

\section{Statistik Deskriptif}

Statistik deskriptif digunakan untuk memberikan gambaran atau deskripsi atas variabel-variabel penelitian. Pengukuran yang digunakan dalam penelitian ini adalah nilai maksimum, nilai minimum, mean, dan standar deviasi untuk setiap indikator variabel. Tabel 3 menunjukan statsistik deskriptif 180 observasi untuk semua variabel dan indikator-indikatornya.

\section{Pengujian Hipotesis}

Inner model adalah modal struktural yang menghubungkan antar variabel laten, yaitu variabel intellectual capital, corporate governance, financial performance, dan market performance. Pengujian inner model atau model struktural dilakukan untuk melihat hubungan antar konstruk, nilai signifikansi dan R-square dari model penelitian.

Tabel 4 menunjukkan bahwa nilai $R$ square perusahaan keuangan periode 20072011 adalah 0,342, artinya variabel Intellectual capital dan corporate governance dengan dikendalikan oleh variabel kontrol mampu menjelaskan variabel Financial Performance sebesar 34,2 persen, sisanya dijelaskan oleh variabel lain yang tidak diteliti dalam penelitian ini. Begitu juga dengan $R$-square Market yaitu sebesar 0,344, berarti bahwa variabel Intellectual Capital dan corporate governance dengan dikendalikan oleh variabel kontrol mampu menjelaskan variabel market performance sebesar 34,4 persen. Semakin besar angka R-square menunjukkan semakin besar variabel independen tersebut dapat menjelaskan variabel dependen, sehingga semakin baik persamaan struktural.

Tabel 5 menunjukkan hasil pengujian hipotesis. Arah pengujian di interpretasikan dengan melihat koefisien original sample estimate pada results for inner weight yang menunjukkan hubungan antara variabel yang dihipotesiskan. Signifikansi hubungan antar variabel ditunjukan oleh besarnya P-value koefisien variabel. Hasil pengujian dan pembahasan berikut. 
Tabel 3: Statistik Deskriptif

\begin{tabular}{|c|c|c|c|c|c|}
\hline \multicolumn{6}{|c|}{ Intellectual Capital (VAIC ${ }^{\mathrm{TM}}$ ) } \\
\hline & $\mathrm{N}$ & Minimum & Maximum & Mean & Std. Deviation \\
\hline VACA & 180 & -.501 & 1.552 & .31307 & .216502 \\
\hline VAHU & 180 & -1.811 & 23.860 & 3.4844 & 3.320627 \\
\hline STVA & 180 & -.228 & 1.552 & .58080 & 227753 \\
\hline VAIC & 180 & -.760 & 24.932 & 4.3783 & 3.433289 \\
\hline \multicolumn{6}{|c|}{ Corporate Governance } \\
\hline & $\mathrm{N}$ & Minimum & Maximum & Mean & Std. Deviation \\
\hline UDK & 180 & 2 & 8 & 4.37 & 1.753 \\
\hline PKI & 180 & .000 & 1.000 & 47778 & . 163728 \\
\hline KA & 180 & 0 & 8 & 3.45 & 1.220 \\
\hline KPM & 180 & .000 & .721 & .06090 & .130957 \\
\hline KPI & 180 & .001 & .999 & .65334 & .241602 \\
\hline \multicolumn{6}{|c|}{ Financial Performance } \\
\hline & $\mathrm{N}$ & Minimum & Maximum & Mean & Std. Deviation \\
\hline ROA & 180 & .001 & .284 & .04066 & .042417 \\
\hline ROE & 180 & .008 & .947 & .15475 & .105709 \\
\hline GR & 180 & -.595 & 1.857 & .22476 & .307524 \\
\hline ATO & 180 & .052 & .977 & .25824 & .232371 \\
\hline \multicolumn{6}{|c|}{ Market Performance } \\
\hline & $\mathrm{N}$ & Minimum & Maximum & Mean & Std. Deviation \\
\hline PER & 180 & .744 & 254.167 & 15.5302 & 22.939882 \\
\hline HS & 180 & 41 & 12700 & 1431.77 & 2271.990 \\
\hline MBV & 180 & .124 & 6.319 & 1.74019 & 1.272473 \\
\hline Tobin & 180 & .110 & 3.159 & 1.02492 & .390512 \\
\hline \multicolumn{6}{|c|}{ Variabel Kontrol } \\
\hline & $\mathrm{N}$ & Minimum & Maximum & Mean & Std. Deviation \\
\hline SIZE & 180 & 10.695 & 14.742 & 12.70622 & 1.019045 \\
\hline DER & 180 & .350 & 17.492 & 5.28336 & 4.364416 \\
\hline
\end{tabular}

Tabel 4: NilaiR- Square

\begin{tabular}{cc}
\hline Variabel & R-square \\
\hline Financial & 0.342 \\
Market & 0.344 \\
\hline
\end{tabular}

Tabel 5: Hasil Pengujian Hipotesis

\begin{tabular}{lcccc}
\hline \multicolumn{1}{c}{ Koefisien Variavel } & $\begin{array}{c}\text { original } \\
\text { sample } \\
\text { estimate }\end{array}$ & $\begin{array}{c}\text { Standard } \\
\text { deviation }\end{array}$ & T-Statistic & P-value \\
\hline IC $\rightarrow$ Financial & 0.281 & 0.080 & 3.499 & 0.000 \\
CG $\rightarrow$ Financial & 0.332 & 0.077 & 4.328 & 0.000 \\
Control $\rightarrow$ Financial & -0.607 & 0.094 & 6.446 & 0.000 \\
Financial $\rightarrow$ Market & 0.425 & 0.111 & 3.840 & 0.000 \\
IC $\rightarrow$ Market & -0.106 & 0.073 & 1.443 & 0.075 \\
CG $\rightarrow$ Market & 0.269 & 0.068 & 3.966 & 0.000 \\
Control $\rightarrow$ Market & 0.364 & 0.080 & 4.568 & 0.000 \\
\hline
\end{tabular}




\section{Intellectual Capital terhadap Financial Performance}

Tabel 5 menunjukan bahwa variabel intellectual capital memiliki pengaruh positif signifikan terhadap financial performance dengan nilai koefisien original sample estimate sebesar 0,281 dan signifikansi pada alpha $1 \%$. Dengan demikian hipotesis pertama didukung data. Temuan tersebut memberikan makna bahwa semakin tinggi nilai intellectual capital yang dimiliki oleh perusahaan keuangan, maka financial performance perusahaan tersebut juga akan semakin meningkat. Artinya perusahaan yang mengelola sumberdaya intelektualnya secara maksimal mampu menciptakan value added dan competitive advantage yang akan bermuara terhadap peningkatan financial performance perusahaan.

Hasil ini memberikan kontribusi yang kuat pada teoristakeholderyang menekankan pada laba akuntansi dan keakuratan value added dalam menentukan return. Hasil pengujian ini juga mendukung dengan resourcebased theory yang menjelaskan bahwa perusahaan dapat mempertahankan produktivitas dengan keunggulan kompetitif yang dimiliki perusahaan dengan cara mengimplementasikan strategi untuk menciptakan value added dalam hal ini intellectual capital yang tidak mudah ditiru oleh pesaing perusahaan.

Hasil penelitian yang menemukan adanya pengaruh positif intellectual capital terhadap financial performance perusahaan sejalan dengan temuan empiris Belkaoui (2003), Astuti dan Sabeni (2005), Tan et al. (2007), Ulum et al. (2008), Solikhah et al. (2010), dan Ningrum (2012).

Dalam penelitian ini hanya indikator VAHU dan STVA yang membentuk konstruk VAIC $^{\mathrm{TM}}$, sedangkan VACA tidak. Dan dari ketiga komponen $\mathrm{VAIC}^{\mathrm{TM}}$, indikator VAHU yang memiliki nilai rata-rata tertinggi daripada indikator lainnya. Rasionalisasi yang mampu menjelaskan hal tersebut adalah bahwa penelitian ini mengambil sampel perusahaan keuangan yang masih menitikberatkan kepada penggunaan tenaga manusia untuk menghasilkan produk dan jasa serta sumberdaya struktural seperti infrastruktur, jaringan, sistem informasi, maupun teknologi yang berkonstribusi besar terhadap penciptaan value added bagi suatu perusahaan. Hasil ini sesuai dengan teori human capital yang menyatakan bahwa human capital yang produktif dengan tingkat keahlian, pengetahuan dan pengalaman serta tingkat kesehatan yang tinggi dapat menguntungkan perusahaan dan menjadi unsur potensial dalam peningkatan produktivitas dan profitabilitas. Sedangkan sumberdaya fisik (VACA), perusahaan keuangan belum menitikberatkan kepada penggunaan mesin dan peralatan untuk produksi barang dan jasa. Physicalasset pada perusahaan knowledge based bukan merupakan asset utama yang dapat meningkatkan kinerja perusahan.

Perusahaan sektor keuangan di Indonesia periode 2007-2011 mulai menyadari pentingnya pengelolaan Intellectual capital dengan memanfaatkan keahlian karyawan, prosedur, efisiensi, dan sistem data perusahaan yang mempermudah dalam mengakses informasi yang relevan serta dengan adanya dukungan dalam pengembangan ide dan produk baru, maka perusahaan keuangan mampu untuk menilai, memprediksi, dan meningkatkan kinerja keuangan perusahaan.

\section{Intellectual Capital terhadap Market Performance}

Pengaruh intellectual capital terhadap market performance tidak didukung oleh data yang ada. Terlihat dari koefisien original sample estimatenya bernilai negatife $(-0,106)$ dan tidak signifikan pada alpha 5\%. Hasil ini membuktikan bahwa intellectual capital berpengaruh negatif tidak signifikan terhadap market performance perusahaan keuangan periode 2007-2011. Hipotesis kedua tidak didukung data. Hasil penelitian ini mungkin menunjukkan bahwa penghargaan pasar terhadap suatu perusahaan bukan didasarkan pada sumberdaya manusia dan struktural. Investor masih lebih banyak terfokus dengan kepentingan jangka pendek, yaitu meningkatkan return keuangan. Investor kurang mepertimbangkan aspek sumberdaya manusia yang diakui sebagai sumber komparatif 
perusahaan ketika mengambil keputusan investasinya di perusahaan sampel.

Hasil ini juga dapat diinterprestasi bahwa semakin tinggi nilai intellectual capital perusahaan semakin rendah market performance pada perusahaan yang menjadi sampel. Hasil penelitian ini tidak selaras dengan penelian Jaafari (2013) dan Chen et al. (2005) yang menyatakan bahwa investor akan memberikan penilaian lebih terhadap perusahaan yang memiliki sumberdaya intelektual yang tinggi dan Intellectual capital diyakini memegang peran penting dalam meningkatkan nilai perusahaan di mata pasar. Untuk konteks perusahaan keuangan di Indonesia periode 20072011, intellectual capital tidak mempengaruhi market performance. Karena adanya kemungkinan bahwa pengaruh intellectual capital terhadap market performance tidak dalam selisih 1 tahun, tetapi dua tahun atau tiga tahun berikutnya. Karenanya penelitian ini belum bisa menunjukkan bahwa intellectual capital yang tinggi juga akan meningkatkan market performance pada perusahaan keuangan dan sahamnya akan banyak diminati oleh investor sehingga harga saham cenderung menjadi naik. Temuan ini sejalan dengan penelitian Gan dan Saleh (2008).

\section{Corporate Governance terhadap Financial Performance}

Koefisien original sample estimate corporate governance terhadap financial performance adalah sebesar 0,332 dan signifikan pada alpha $1 \%$. Hasill ini menunjukkan bahwa corporate governance berpengaruh positif dan signifikan terhadap financial performance perusahaan. Hipotesis ketiga didukung data. Hasil ini mengindikasikan bahwa dengan adanya tata kelola perusahaan yang baik dan terkendali, keselarasan tujuan antara seluruh pihak yang berkepentingan terhadap perusahaan dapat terwujud sehingga seluruh elemenelemen yang terkait dapat bekerja sama dalam menjalankan kegiatan bisnis secara maksimal. Kinerja keuangan perusahaan pun akan mengalami peningkatan seiring dengan peningkatan pengelolaan perusahan dalam mencapai tujuannya.
Sejalan dengan Jensen dan Meckling (1976) mengemukakan bahwa perusahaan dengangovernance yang baik akan memiliki kinerja keuangan yang lebih efisien. Sama halnya juga dengan penelitian yang dilakukan Klapper dan Love (2002) yang berhasil menemukan adanya hubungan positif antara corporate governance dengan kinerja keuangan.

Perusahaan keuangan yang terdaftar di BEI periode 2007-2011 menunjukkan bahwa pentingnya seperangkat sistem yang mengatur dan mengendalikan perusahaan untuk menciptakan nilai tambah bagi perusahaan dan para pemangku kepentingan. Corporate governance mengendalikan dan mengarahkan perusahaan agar mencapai keseimbangan antara kekuatan serta kewenangan perusahaan dalam memberikan pertanggungjawabannya kepada para shareholders khususnya, dan stakeholder pada umumnya. Oleh karenanya hasil ini menunjukkan perusahaan memiliki kesadaran yang tinggi untuk menerapkan good corporate governance sebagai suatu kebutuhan, bukan hanya sekedar kepatuhan terhadap regulasi yang telah ada. Manajemen perusahaan tertarik dengan manfaat jangka panjang dari penerapan good corporate governance tersebut.

\section{Corporate Governance terhadap Market Performance}

Variabel corporate governance didukung oleh data yang ada dalam membuktikan adanya pengaruh positif terhadap market performance perusahaan dengan koefisien original sample estimate 0,269 dan t-statistik 3,96 tersebut signifikan pada alpha $1 \%$. Artinya corporate governance berpengaruh positif dan signifikan terhadap market performance pada perusahaan keuangan. Hipotesis keempat didukung data.

Secara teoritis, corporate governance berhubungan positif dengan nilai perusahaan (Labelle 2002). Pernyataan ini didukung oleh Kinsey (2001) yang menyatakan bahwa investor bersedia membayar premium yang lebih tinggi untuk perusahaan yang menerapkan corporate governance yang baik. Peneli tian membuktikan bahwa corporate gover- 
nance memiliki dampak positif terhadap market performance, menunjukkan bahwa pelaksanaan corporate governance yang baik secara konsisten dan konsekuen di setiap kegiatan bisnis serta menjadikannya sebagai budaya kerja yang berlaku di perusahaan, dapat mendukung tujuan perusahaan baik pertumbuhan usaha, profitabilitas, meningkatkan nilai pemegang saham dan pemangku kepentingan lainnya, serta meningkatkan kemampuan agar keberlangsunganusaha jangka panjang dapat dicapai. Investor akan merasa aman atas investasinya, cenderung memperoleh return sesuai dengan harapannya dan bersedia membayar premium kepada perusahaan yang menerapkan good corporate governance. Corporate governance mengindikasikan dapat memberikan keyakinan kepada investor bahwa mereka akan menerima return atas dana yang diinvestasikan. Aspek-aspek corporate governance dipandang sebagai mekanisme kontrol yang tepat untuk mengurangi konflik keagenan.

Penelitian ini menunjukkan bahwa pengungkapan corporate governance yang diproksikan dengan ukuran dewan komisaris, komite audit, kepemilikan manajerial, dan kepemilikan institusional berpengaruh positif terhadap market performance. Hasil penelitian ini mendukung hasil penelitian Black et al. (2003), Klapper dan Love (2002) dan Kinsey (2001).

\section{Financial Performance terhadap Market Performance}

Hipotesis ke 5 mengenai pengaruh financial performance terhadap market performance didukung oleh data yang ada. Nilai koefisen original sample estimate 0,425 dan signifikan pada alpha $1 \%$. Dengan demikian semakin baik suatu perusahaan dalam mengelola aset dan kekayaan perusahaan melalui kinerja keuangan yang baik sehingga kinerja pasar perusahaan yang memberikan persepsi pasar tentang nilai perusahaan semakin meningkat. Hasil penelitian ini sejalan dengan penelitian Yuniasih dan Wirakusuma (2007).

Hasil penelitian tersebut juga mengindikasikan bahwa manajemen menyadari pentingnya penerapan kinerja keuangan yang baik sebagai suatu investasi yang bermanfaat bagi perusahaan dalam jangka waktu panjang. Manajemen juga menyadari bahwa kinerja keuangan bukan hanya internal perusahaan tetapi juga untuk pemangku kepentingan lainnya. Sesuai dengan teori signaling bahwa informasi yang disajikan perusahaan tertuang dalam Laporan keuangan sebagai laporan yang menunjukkan bagaimana kinerja keuangan perusahaan selama kurun waktu tertentu tehh direspon baik oleh investor.

Para stakeholder lebih menyenangi perusahaan yang bisa menciptakan nilai bagi kepentingannya. Jika stakeholdernya calon investor maka kepentingannya terhadap perusahaan adalah perusahaan kinerjanya baik sehingga perusahaan laba dan investor juga mendapat keuntungan dari modal yang ditanamkan di perusahaan tersebut. Sehingga perusahaan yang kinerjanya baik maka akan mampu memenuhi kepentingan stakeholder sehingga sahamnya banyak diminati dan harga sahamnya menjadi naik.

Kinerja keuangan perusahaan yang benar-benar baik maka perusahaan harus memberi signal kepada pihak eksternal dengan melakukan tindakan atau kebijakan yang tidak bisa dilakukan oleh perusahaan lain yang tidak memiliki kinerja yang sama. Hal ini dijelaskan dalam teori signaling. Contohnya dalam pemberian deviden, pemberian deviden merupakan signal dari perusahaan bahwa perusahaannya dalam kondisi baik atau laba, karena perusahaan yang dalam kondisi merugi tidak akan mampu memberikan deviden, kalau pun ingin memberikan deviden itu akan menjadikan biaya yang besar bagi perusahaan tersebut. Perusahaan telah mengkomunikasikan pesan kinerja keuangan secara tepat sehingga makna dari pengungkapan kinerja keuangan dapat diterima dengan baik oleh para investor.

\section{SIMPULAN}

Berdasarkan hasil pengujian dan pembahasan sebagaimana telah disajikan sebelumnya, maka dapat ditarik kesimpulan bahwa intellectual capital dan corporate governance berpengaruh positif signifikan terhadap financial 
performance perusahaan keuangan yang terdaftar di Bursa Efek Indonesia periode 20072011. Akan tetapi, intellectual capital tidak berpengaruh terhadap market performance. Hasil lain juga menunjukan bahwa corporate governance dan financial performance berpengaruh positif signifikan terhadap market performance perusahaan keuangan yang terdaftar di Bursa Efek Indonesia.

Hasil ini berimplikasi serius bagi pihak perusahaan. Intellectual capitalyang terdapat di dalam perusahaan harus dapat dikelola oleh pihak manajer karena Intellectual capital efektif untuk menciptakan dan mengembangkan nilai bagi perusahaan (firm's value creation). Investasi dalam human capital merupakan suatu investasi yang penting dan memiliki nilai ekonomi bagi perusahaan karena dapat meningkatkan produktivitas. Human capital yang produktif dengan tingkat keahlian, pengetahuan dan pengalaman serta tingkat kesehatan yang tinggi dapat menguntungkan perusahaan dan menjadi unsur potensial dalam peningkatan produktivitas. Human capital akan meningkat jika perusahaan mampu menggunakan pengetahuan yang dimiliki oleh karyawannya. Hasil tersebut juga mengindikasikan bahwa dalam industri yang berbasis pengetahuan, human capital menjadi sumberdaya yang paling penting, karena sumberdaya ini merupakan biaya yang utama dalam proses produksi perusahaan. Human capital dapat mendukung terciptanya modal struktural dan modal pelanggan yang menjadi inti dari hak kekayaan intelektual.

Keberadaaan corporate governance juga sangat penting bagi perusahaan. Hasil penelitian ini mengimplikasikan bahwa penerapan corporate governance yang baik dan menjadikannya sebagai budaya kerja yang berlaku di perusahaan, dapat mendukung tujuan perusahaan baik pertumbuhan usaha, profitabilitas, meningkatkan nilai pemegang saham dan pemangku kepentingan lainnya, serta meningkatkan kemampuan agar keberlangsungan usaha jangka panjang dapat dicapai. Dengan demikian para investor akan merasa aman dalam berinvestasi dan mungkin akan memperoleh return sesuai dengan harapannya dan bersedia membayar premium kepada perusahaan yang menerapkan good corporate governance.

Sebagaimana lazimnya suatu penelitian empiris, hasil penelitian ini juga mengandung keterbatasan. Sampel yang digunakan dalam penelitian ini hanya terbatas pada perusahaan keuangan yang terdaftar di Bursa Efek Indonesia (BEI) periode 2007-2011 (5 Tahun) sehingga generalisasi ini hanya terbatas pada perusahaan yang ada. Penelitian selanjutnya disarankan untuk meneliti sektor lainnya seperti sektor manufaktur, sektor konstruksi, transportasi, dan lain-lain dengan menggunakan tahun yang lebih baru dan periode yang lebih lama untuk mendapatkan hasil yang lebih baik. Di samping itu penelitian ini terbatas pada proksi yang digunakan untuk mengukur financial performance yaitu ATO, ROA, ROE, dan GR, mengukur market performance proksi yang digunakan MBV, PER, PBV, dan Tobin, dan corporate governance hanya ukuran dewan komisaris, proposrsi komisaris independen, komite audit, kepemilikan manajerial, dan kepemilikan institusional. Penelitian selanjutnya agar dapat mempertimbangkan proksi corporate governance lainnya seperti komposisi dewan direksi dan kualitas audit, dan untuk proksi market performance lain seperti Annual Stock Return (ASR), market capitalization, dan earning per share (EPS,) dan proksi financial performance lainnya seperti employee productivity.

\section{DAFTAR REFERENSI}

Astuti. 2005. Hubungan modal intelektual dan business performance dengan diamond specification: Sebuah perspektif akuntansi. Simposium Nasional Akuntansi VIII Solo, 15-16 September 2005.

Belkaoui, A.R. 2003. Intellectual capital and firm performance of US multinational firms: A study of the resource-based and stakeholder views. Journal of Intelectual Capital 4 (2): 215-226.

Boediono, G. 2005. Kualitas laba: Studi pengaruh mekanisme corporate governance dan dampak manajemen laba 
dengan menggunakan analisis jalur. Simposium Nasional Akuntansi VIII.

Bontis, N., Keow, W.C.C., dan Richardson, S. 2000. Intellectual Capital and Business Performance in Malaysian Industries. Journal of Intellectual Capital 1 (1): 85-100.

Bontis, N. 2001. Assessing knowledge assets: a review of the models used to measure intellectual capital. International Journal of Management Review 3 (1): 41-60.

Brigham, E. F., dan J. F. Houston. 2011. Dasar-dasar manajemen keuangan (terj.), Jilid 2, Edisi sebelas. Jakarta: Salemba Empat.

Brown, L. D., dan M. L. Caylor. 2006. Corporate governance and firm performance. Journal of Accounting and Public Policy 25: 409-434.

Cadbury Committee Report. 1992. Report of committee on the financial aspects of corporate governance. London: Gee

Chen, M., S.J. Cheng., dan Y. Hwang. 2005. An empirical investigation of the relationship between intellectual capital and firms' market value and financial performance, Journal of Intellectual Capital 6 (2): 159-176.

Dewi, C. P. 2011. Pengaruh intellectual capital terhadap kinerja keuangan pada perusahaan manufaktur yang terdaftar di BEI tahun 2007-2009. Semarang: Fakultas Ekonomi Universitas Dipenogoro.

Edvinsson, L., dan M. Malone. 1997. Intellectual capital: Realizing your company's true value by finding its hidden brain power New York: Harper Collins.

Eisenhardt, K. M. 1989. Agency theory: An assesment and review. Academy of Management Review 14 (1): 57-74.

Eng L. L., danMak. Y. T. 2003. Corporate governance and voluntary disclo-
sure.Journal of Accounting and Public Policy 22 (4): 325-345.

Firer, S., dan S.M. Williams. 2003. Intellectual capital and traditional measures of corporate performance. Journal of Intellectual Capital 4 (3): 348-360.

Gan, K., dan Z. Saleh. 2008. Intellectual capital and corporke performance of technology-intensive companies: Malaysia evidence. Asian Journal of Business and Accounting 1 (1): 113130.

Ghozali, I. 2008. Structural equation modeling metode alternatif dengan partial least square (PLS). Semarang: Badan Penerbit Universitas Diponegoro.

Horne, J. C., dan J. J. Whacowicz. 2009. Prinsip-prinsip manajemen keuangan edisi indonesia. Jakarta: Salemba Empat.

Husnan, S., dan E. Pudjiastuti. 2006. Dasardasar manajemen keuangan. Yogyakarta: UPP STIM YKPN.

Ikatan Akuntan Indonesia. 2002. Pernyataan standar akuntansi keuangan no. 19. Jakarta: Salemba Empat.

Imaningati. 2007. Pengaruh intellectual capital pada nilai pasar perusahaan dan kinerja perusahaan. Semarang: Program Studi Magister Akuntansi Program Pascasarjana Universitas Diponegoro.

Jaafari, E. 2013. Intellectual capital and its effects on firms' market value and financial performance in Iran: An investigating pulic model. Research Journal of Recent Sciences 2 (3): 1-6.

Jensen, M. C., dan Meckling, W. H. 1976. Theory of the firm: Management behaviour, agency cost and ownership structure. Journal of Finance Economic 3 (4): 305-360.

Kavida, V., dan N. Sivakoumar. 2007. The impact of intellectual capital on international business - An analysis of investments in intellectual capital and 
export performance. International Journal of Arts \& Sciences 4 (15): 213-223.

Klapper, L. F., dan I. Love. 2002. Corporate governance, investor protection, and performance in emerging markets. World Bank Working Paper.

Kinsey, M. 2001. Excecutif compensation structure, ownership, and firm performance. Journal of Financial Economics 38: 163-184.

Komite Nasional Kebijakan Governance. 2004. Pedoman tentang komisaris independen. http://www.governanceindonesia.or.id/main.htm (diakses 19 April 2013).

Kusuma, A. B. R. 2011. Pengaruh corporate governance terhadap kinerja pasar perusahaan. Yogyakarta: Fakultas Ekonomi Universitas Islam Indonesia.

Kusumawati, D., dan B. Riyanto. 2005. Corporate governance dan kinerja: Analisis pengaruh compliance reporting dan struktur dewan terhadap kinerja. Simposium Nasional Akuntansi VIII.

Labelle, 2002. Determinant of corporate decision to disclose social information. accounting. Auditing and Accountability Journal 2 (1): 36-51.

Mahmud, M. 2013. Pengaruh intellectual capital terhadap kinerja keuangan dan nilai pasar pada perusahaan manufaktur yang terdaftar di bursa efek indonesia (pengujian dengan persamaan simultan). Skripsi., Fakultas Ekonomi Universitas Islam Indonesia.

Nandaria, D. 2013. Pengaruh intellectual capital dan corporate governance terhadap business performance: pendekatan persamaan struktural. Skripsi., Fakultas Ekonomi Universitas Islam Indonesia.

Ningrum, N. R. 2012. Analisis pengaruh intellectual capital dan corporate governance terhadap financial performance. Semarang: Fakultas Ekonomi dan Bisnis Universitas Diponegoro.

Organization for Economic Cooperation and Development (OECD). 1999. International symposium on measuring and reporting intellectual capital: Experience, issues and prospects. Amsterdam.

Penrose, E.T. 1959. Thetheory ofthe growthofthefirm. Great Britain: Basil Blackwell\&Mott Ltd.

Pulic, A. 1998. Measuring the performance of intellectual potential in knowledge economy. Paper presented at the 2 nd McMaster word congress on Measuring and managing intellectual capital: Austrian Team for Intellectual Potential.

. 1999. Basic Information on VAIC ${ }^{\text {TM }}$. Available online at: www.vaic-on.net. 2000. An accounting tool for IC management. National Chengchi University, Department of Accounting. Available online: http://www.measuringip.at/Papers/ham99txt.htm

Rani, W. P. 2012. Pengaruh intellectual capital terhadap kinerja pasar dengan struktur kepemilikan dan ukuran perusahaan sebagai variabel kontrol. Yogyakarta: Fakultas Ekonomi Universitas Islam Indonesia.

Sawarjuwono, T., dan A. P. Kadir. 2003. Intellectual capital: Perlakuan, pengukuran, dan pelaporan (sebuah library research). Jurnal Akuntansi dan Keuangan 5 (1): 35-37.

Sembiring. 2005. Karakteristik perusahaan dan pengungkapan tanggung jawab sosial: Study empiris pada perusahaan yang tercatat di bursa efek jakarta. Simposium Nasional Akuntansi VIII.

Siallagan, H., dan M. Machfoedz. 2006. Mekanisme corporate governance, 
kualitas laba dan nilai perusahaan. Simposium Nasional Akuntansi IX.

Solikhah, B., A. Rohman., dan W. Meiranto. 2010. Implikasi intellectual capital terhadap financial performance, growth dan market value; Studi empiris dengan pendekatan simplistic specification. Simposium Nasional Akuntansi XIII Purwokerto.

Starovic, D., dan Marr, B. 2004. Understanding corporatevalue: Managingand reporting intellectual capital. Chartered Institute of Management Accountants.

Stewart, T.A. 1991. Brain power: How intellectual capital is becoming america's most valuable asset. FORTUNE: 4460 .

Susanto, A.B. 2007. Resource based versus market based. Eksekutif 338: 24-25.

Sveiby, K.E. 1997. The new organizational wealth: Managing and measuring knowledge-based assets. San Francisco: Berrett-Koehler Publishers.

Tan, H. P., Plowman, D., dan Hancock, P. 2007. Intellectual capital and financial returns of companies. Journal of Intellectual Capital 8 (1): 76-95.

Ujiyantho, M. A., dan B. A. Pramuka. 2007. Mekanisme corporate governance, manajemen laba, dan kinerja ke- uangan. 26-28 Juli 2007. Simposium Nasional Akuntansi X, Makassar.

Ulum, G. I., dan A. Chariri. 2008. Intellectual capital dan kinerja keuangan perusahaan: suatu analisis dengan pendekatan partial least squares. SNA $X$ 1: 1-32.

Ulum, I. 2009. Intellectual capital: Konsep dan kajian empiris.Yogyakarta: Graha Ilmu.

Wardhani, R. 2008. Tingkat konservatisme akuntansi di indonesia dan hubungannya dengan karakteristik dewan sebagai salah satu mekanisme corporate governance. Simposium Nasional AkuntansiXI, Pontianak.

Wijaya, L.R., dan Wibawa, B.A. 2010. Pengaruh keputusan investasi, keputusan pendanaan dan kebijakan dividen terhadap nilai perusahaan. Simposium Nasional Akuntasi XIII, Purwokerto.

Williams, S. M. 2001. Are intellectual capital performance and disclosure practices related?. Journal of Intellectual Capital 2 (3): 192-203.

Yuniasih, N. W., dan Wirakusuma, M. G. 2007. Pengaruh kinerja keuangan terhadap nilai perusahaan dengan pengungkapan corporatesocial responsibility dan good corporate governance sebagai variabel pemoderasi. Universitas Udayana, Bali. 